\title{
Społeczno-kulturowe uwarunkowania demokratyzacji edukacji na Tajwanie
}

\section{KEYWORDS}

Taiwan, educational goals, school improvement; educational reform

\begin{abstract}
Nowosad Inetta, Społeczno-kulturowe uwarunkowania demokratyzacji edukacji na Tajwanie [Social and cultural preconditions for the process of democratization in Taiwanese education]. Kultura - Społeczeństwo - Edukacja nr 2(14) 2018, Poznań 2018, pp. 137-154, Adam Mickiewicz University Press. ISSN 2300-0422. DOI 10.14746/ kse.2018.14.12.
\end{abstract}

The article focuses on changes introduced in Taiwan's education since 1949, which reflect the social changes taking place in this country. Special attention is drawn to the origin and the course of two particularly important processes, i.e. democratisation and taiwanisation, which have radically changed the face of education, revealing Taiwan's 'balancing' between the East and the West. While depicting their essence, also complex links with Taiwan's policies towards China and its orientation onto economic growth were taken into account.

\section{Wprowadzenie}

Tajwan zdecydowanie wyróżnia się na tle innych krajów i regionów Azji. Jego unikatowy status można określić jako formę przejściową między narodem a państwem. Jest demokracją bez narodowości i za taką uznaje go społeczność międzynarodowa (Copper, 2003: 31-33). Niezdolność do ogłoszenia niezależności wynika z obawy przed zagrożeniem wojskowym ze strony Chińskiej Republiki Ludowej (ChRL). 
Niestabilne relacje sąsiedzkie po obu stronach Cieśniny Tajwańskiej stanowiły już na początku XIII wieku problem zarówno dla Chin, jak i Tajwanu. Na przestrzeni dziejów pojawiało się wiele sporów i konfliktów. Pierwsze oficjalne relacje pomiędzy sąsiadami miały miejsce w 1206 roku, gdy mongolski wódz Dżyngis-chan (pierwszy z dynastii Yuan) włączył Tajwan w posiadłości chińskie (Wu-Ping, 2007: 104). Od tego czasu znaczenie wyspy było dla Chin kontynentalnych różne. Na 37 lat skolonizowali ją Holendrzy, ale już w 1661 roku wyspa z powrotem została przyłączona do sił kontynentalnych, a kolonizatorzy wypędzeni. Po 1880 roku na krótko jej część znalazła się pod okupacją francuską. Znamienne dla losów społeczności Tajwanu okazało się przekazanie wyspy Japonii po przegraniu z nią wojny w 1895 roku i utrzymanie w swoich granicach do 1945 roku. Ostatecznie Tajwan został przekazany Chinom po II wojnie światowej. Mimo różnych wpływów doświadczanych przez ludność Tajwanu okres panowania Japonii oceniany jest ambiwalentnie. $Z$ jednej strony była to bowiem bezwzględna władza despotyczna, jednak z drugiej przyczyniła się do rozwoju materialnego i kulturalnego wyspy.

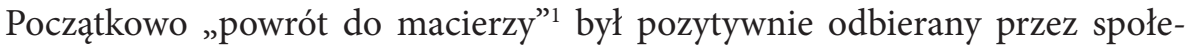
czeństwo, jednak narastały napięcia, które 28 lutego 1947 roku doprowadziły do wybuchu otwartej wrogości wobec nacjonalistycznego rządu. Konflikt wewnętrzny w Chinach doprowadził 1 października 1949 roku do proklamowania Chińskiej Republiki Ludowej. Zdarzenie to miało dalekie konsekwencje dla Tajwanu. W grudniu 1949 roku na jego teren uciekł nacjonalistyczny rząd Republiki Chin kierowany przez Kuomintang (KMT). Początkowo planowano wzmocnić własne siły i przygotować się do przejęcia władzy i całych Chin. Z zamiarem tymczasowości doszło do ukonstytuowania się Tajwanu jako Republiki Chińskiej na Tajwanie. Ludność chińska została w ten sposób podzielona na nacjonalistów zamieszkujących wyspę i komunistów na kontynencie. Każda ze stron zgłaszała roszczenia do reprezentowania całości Chin. W sytuacji niejasnej przyszłości Tajwanu po 1949 roku nic nie wskazywało na znalezienie rozwiązania, które satysfakcjonowałoby obydwie strony konfliktu. Jednakże napięcia występowały nie tylko po obu stronach Cieśniny Tajwańskiej, ale także na samym Tajwanie. Rządy Kuomintangu na wyspie rozpoczęły się od wprowadzenia stanu wojennego i autorytarnej władzy, która trwała do chwili uchylenia dekretu o stanie wojennym w 1987 roku i zastą-

1 W roku 1911 na kontynencie powstała Republika Chin (RCh), a 1 stycznia 1912 roku wprowadzone zostały rządy republikańskie. Tym samym po zakończeniu II wojny światowej Tajwan znalazł się pod rządami Republiki Chin i systemu „ludu, przez lud i dla ludu” - określenie wprowadzone przez twórcę i założyciela nowego państwa dr. Sun Yat-sena, za: Wu-Ping, 2007. 
pienia go mniej rygorystycznym prawem o bezpieczeństwie narodowym. Mimo trudnej sytuacji Tajwan rozwijał się w niebywale szybkim tempie.

Od 1949 roku, w sytuacji niejasnej przyszłości wyspy, Tajwan w sposób wysoce elastyczny balansował między Wschodem a Zachodem. Można powiedzieć, że od tego czasu znajduje się w fazie nieustannych przemian. Ich dynamika zwraca uwagę na umiejętność wykorzystania własnego potencjału w kształtowaniu i realizacji strategicznych interesów. Jest też wysoce pragmatyczny, pozycjonując się jako 'obrotowy' w handlu w basenie Morza Południowochińskiego. Strategia ta przynosi efekty. Obecnie Tajwan jest dwudziestą gospodarką świata i wytwarza prawie 1\% światowego PKB. Ewolucja potencjału gospodarczego wyspy stała się kluczowym atrybutem Tajwanu, sprzyjającym wzrostowi konkurencyjności jego gospodarki. Zaważyło na tym zastąpienie gospodarki opartej na wysokich nakładach pracy przemysłem wykorzystującym zaawansowane technologie. W efekcie Tajwan stał się wiodącym państwem na światowym rynku informatycznym.

Zmiany, jakie dokonały się na Tajwanie w ciągu ostatnich 50 lat, nie dotyczyły tylko i wyłącznie gospodarki. Na wyspie doszło również do gwałtownych zmian politycznych i społeczno-kulturowych. Ich intensywność wzrosła po zniesieniu stanu wojennego (1987). Wówczas to tajwański ustrój polityczny zmienił się z autorytarnego na demokratyczny, a pierwsze w pełni demokratyczne wybory prezydenckie odbyły się w 1996 roku. Z tymi przemianami wiązały się liczne reformy społeczne (w tym nadanie praw kobietom, sformalizowanie praw konsumentów, pluralizmu politycznego i ochrony środowiska).

Ważnym wskaźnikiem społecznych zmian jest edukacja, która stanowi fundament narodu. Szkolnictwo jest wzorowane na amerykańskim systemie edukacyjnym. Od 1968 roku edukacja obowiązkowa obejmuje dziewięć lat nauki (wiek 7-15 lat). W strukturze szkolnictwa pierwszy szczebel stanowi 6-letnia szkoła podstawowa (7-12 lat), następne trzy lata przypadają na gimnazjum (13-15 lat), trzy lata liceum (16-18), cztery do siedmiu lat college'u lub uniwersytetu. Alternatywne do akademickiej ścieżki kształcenia przewidują programy edukacji technicznej i zawodowej. Ważne uzupełnienie współczesnego oblicza edukacji i bogatej oferty edukacyjnej stanowią dostępne dla obywateli w każdym wieku specjalne programy edukacyjne oraz programy kształcenia ustawicznego dla dorosłych. Bez wątpienia decyzja z 1968 roku o przedłużeniu obowiązkowej nauki z sześciu do dziewięciu lat jest jedną z najwyżej ocenianych zmian wprowadzonych w edukacji po 1949 roku. wspaniałe osiągnięcia tajwańskich uczniów w międzynarodowych rankingach i pomiarach międzynarodowych ostatnich dwóch dekad, którymi może poszczyć się współczesny Tajwan, są niezwykłe, gdy zauważy się stosunkowo krótki czas, 
w którym te dziewięć lat nauki obowiązywało, a od 2012 roku okres obowiązkowej edukacji wydłużono o kolejne 3 lata (łącznie jest to 12 lat nauki do18 roku życia)2.

Rząd Tajwanu, dokonując oceny swojej polityki edukacyjnej, mocno podkreśla systematyczną ekspansję i poprawę jakości edukacji realizowaną od 1949 roku, która w specyficzny sposób była powiązana z sektorem gospodarki tego kraju, a mianowicie zmiany edukacji wyprzedzały wzrost gospodarczy. Wprowadzane reformy edukacji dobrze odzwierciedlają także zachodzące $w$ tym kraju zmiany społeczne, które eksponują dwa znaczące procesy: demokratyzacji i tajwanizacji, powiązane z przejściem od jednolitości do różnorodności, od autorytarnej centralizacji do decentralizacji, deregulacji i pluralizmu (Cheng-Sheng, 2007).

\section{Okres autorytarny (1949-1987)}

Po przegranej wojnie domowej z Komunistyczną Partią Chin w 1949 roku partia Kuomintang (KMT) pod dowództwem Czang Kaj-szeka wycofała się na teren Tajwanu i tam rządziła w systemie jednopartyjnym. Przeniesienie rządu centralnego na Tajwan w 1949 roku było oficjalnie traktowane jako stan tymczasowy. Miało to swoje odzwierciedlenie w celach edukacji, które priorytetowo traktowały przygotowanie kompetentnych pracowników do odbudowy kontynentalnej, gdy w przyszłości reżim komunistyczny zostanie obalony. Takie założenia mogły obowiązywać jedynie w czasie stanu wojennego, który obowiązywał w okresie autorytarnym. Były jednakże podstawą kształtującą pogląd rządu na edukację jako proces, który powinien być kontrolowany centralnie i wykorzystywany do państwowych (narodowych) celów (Liu, 1958: 6).

Opór KMT wobec ideologii i praktyk politycznych komunistycznego rządu Chin dobrze odzwierciedlały założenia programowe w zakresie kształtowania wartości i postaw obywatelskich (Doong, 2008: 43-60). Czang Kaj-szek oświadczył w 1968 roku, że edukacja moralna i obywatelska służy przygotowywaniu uczniów do bycia „ludźmi i dobrymi uczniami”, a także „dobrymi Chińczykami, którzy kochają swój kraj i innych (...) oraz doceniają chińskie wartości i kulturę" (Czang Kaj-szek, za: Liu, 2002: 96). Można przyjąć, że podstawy edukacji budowano na dwóch fundamentach uwarunkowanych historycznie: konfucjanizmie i tradycji egzaminów odziedziczonej po Chinach. Meihui Liu w artykule napisanym wspólnie z Chrisem Murphy podkreśla: „my Chińczycy jesteśmy dumni ze swojej

2 Por. Ministry of Education Republic of China, Education in Taiwan, Department of Statistics, Taipei 2013/2014, s. 8-10, https://stats.moe.gov.tw/files/ebook/Education_in_Taiwan/2013-2014_ Education_in_Taiwan.pdf dostęp: 20.12.2017; Clark, 2010. 
długiej historii i tradycyjnej kultury, a Tajwańczycy uważają się za strażników tej tradycji” (Murphy, Liu, 1998: 9-10).

Rząd KMT rozpoczął inicjatywy na rzecz odrodzenia kultury chińskiej poprzez wzmocnienie narodowej edukacji, promowanie języka mandaryńskiego oraz kontynuację konfucjańskiej tradycji i kultury. Działania te rząd KMT uznał za priorytetowe, ponieważ dostrzegał utratę moralnych cnót w chińskiej edukacji na kontynencie i przejmowanie wzorów sowieckich (Lee, 2004: 575-595). Usiłując promować patriotyzm, przyjmowano, zgodnie z tradycją konfucjańską, że edukacja jest siłą kształtującą dobre społeczeństwo, a także, że powinna być dostępna jednakowo dla wszystkich na podstawie zasług. Wysoka wartość przyznana jest harmonii społecznej, która dla jednostki oznacza zanurzenie w społeczeństwie i podporządkowanie swoich potrzeb dobru ogółu (Ho, Lam, Yeh, 2013: 362-367). Tradycja ta stoi ewidentnie w opozycji do silnych podstaw indywidualności i niezależności, wysoce cenionych przez Zachód. Według Douglasa Smitha nawet we współczesnym Tajwanie zachowanie, które jest wyraźnie indywidualne, uznawane jest za 'aberrację' (Smith, 1992: 7, za: Murphy, Liu, 1998: 10).

W okresie autorytarnym administracja rządowa opowiadała się za obowiązywaniem w programach nauczania tradycyjnej konfucjańskiej etyki (przyzwoitość, sprawiedliwość, uczciwość i honor), cnót (lojalność, posłuszeństwo, życzliwość, miłość, wierność, sprawiedliwość, harmonia i pokój) i zasadniczych dogmatów Ruchu Nowego Życia Czang Kaj-szeka: uporządkowanie, czystość, prostota, oszczędność, terminowość i dokładność (Hung, 2007: 300-314). Zgodnie z tezami, iż dobroci można się nauczyć, a społeczeństwo może osiągnąć harmonię tylko poprzez wiedzę, na wszystkich szczeblach szkolnictwa wprowadzone zostały przedmioty kultywujące pożądane wartości (Yao, 2000: 26). Zajęcia lekcyjne nakłaniały uczniów do przeciwstawiania się komunizmowi, podtrzymywania tożsamości narodowej i etnicznej oraz czczenia przywódców politycznych. W szkołach podstawowych obowiązywał przedmiot „życie i etyka”, zaś w gimnazjach „wiedza o społeczeństwie i moralności” obejmowała naukę cnót moralnych podobnych do tych nauczanych na poziomie podstawowym, ale dodatkowo wprowadzano tematy związane z polityką, ekonomią, prawem i kulturą, takie jak Trzy Zasady Ludu: nacjonalizm, demokracja i dobrobyt, wprowadzone przez założyciela KMT Sun Jat-sena (Hung, 2007). Podręczniki były zorganizowane w sekwencji odzwierciedlającej konfucjański wzorzec, który swój początek ma w jednostce, a następnie rozszerza się na większe grupy społeczne i środowiska, jak: rodzina, szkoła, społeczeństwo, państwo i świat. Podobne treści realizowane były w szkołach średnich II stopnia, zaś w szkolnictwie wyższym analizie poddawano poglądy Sun Jat-sena nazywanego powszechnie na Tajwanie „Ojcem Narodu” (Ho, Lam, Yeh, 2013: 364). 
Niektóre przedmioty, szczególnie chiński, historia, nauki społeczne i geografia, były ideologicznie wypaczone. Ponadto od 1968 roku opracowanie podręczników zostało zmonopolizowane przez specjalnie do tego celu powołany instytut (National Institute for Compilation and Translation, NICT) w sektorze ministerstwa edukacji (TMOE). Chi-Ming Lee, dokonując analizy treści zawartych w podręcznikach, zwraca uwagę na sześć obszarów tematycznych: orientację na tradycyjną kulturę, opór wobec komunizmu, gloryfikację narodu, kult przywódców politycznych, skupienie się na etniczności i usprawiedliwienie męskiego szowinizmu. W dalszych analizach uzasadnia trzy główne cechy kształtowania wąskiego umysłu przez tajwańską edukację moralną i są to: utrzymywanie porządku społecznego (strzec narodu), dbałość o idealny wzorzec osoby w zgodzie z zachowaniem wszystkich tradycyjnych wartości oraz wzmocnienie tożsamości chińskiej, a nie tajwańskiej (Lee, 2004).

Egzekwowaniu pożądanych treści sprzyjały centralne rządy i wyspecjalizowane w jego ramach sektory ${ }^{3}$, ale także lokalnie kontrolowana edukacja. Ministerstwo edukacji określiło treść programów nauczania i podręczników, zmuszając uczniów do podejmowania tematów politycznych i ideologicznych. Istotne było przekazywanie kolejnym pokoleniom antykomunistycznej ideologii politycznej i rozpowszechnianie tradycyjnej chińskiej kultury i wartości. Narzucone odgórnie ideały i wartości były obecne w różnych przedmiotach szkolnych, ich rolę często podkreślano w podręcznikach na przykładzie historii bohaterów narodowych lub postaci historycznych z czasów imperialnych (Meyer, 1988: 20). Egzekwowaniu pożądanych treści sprzyjali kontrolowani w procesie mianowania dyrektorzy szkół. Innym aspektem nadzorowania dyscypliny uczniów: wzorów zachowań i nawyków życiowych, był założony w każdej szkole dział dyscypliny (Department of Discipline, DoD). Badania przeprowadzone tym okresie wskazują, iż argumentacja uczniów w kwestiach moralnych opierała się właśnie na promowanych zasadach i wartościach, a nie na umiejętności krytycznego myślenia - podstawie oceny systemów państw zachodnich. Zauważony problem odtwarzania wiedzy został wykorzystany przez kolejnych reformatorów w zmianach programów nauczania (Lee, 2004: 581).

W okresie autorytarnym „celem edukacji elementarnej było wspieranie dobrych (lub dobra) obywateli. Celem kształcenia zawodowego - wyszkolenie zręcznych pracowników w produkcji. Celem edukacja uniwersyteckiej - kształcenie doskonałych liderów” (Liu, 1977: 43). Podział ten, jak również polityka rządu

\footnotetext{
${ }^{3}$ W sektorze tajwańskiego ministerstwa edukacji (TMOE) reaktywowano w 1955 roku założony jeszcze w 1939 roku w Chinach Komitet Dyscypliny i Moralności (Committee of Discipline and Moralisty, CDM), którego celem było wzmocnienie edukacji ideologicznej, za: Lee, 2004.
} 
w zakresie planowania kształcenia siły roboczej o odpowiednich kwalifikacjach, zaważyły na odbudowie gospodarki. Przyjmuje się, iż nacisk na kształcenie zawodowe na Tajwanie stanowił jeden z głównych filarów postępującego od lat 70. XX wieku ciągłego wzrostu gospodarczego (Young, 1995: 122). Równie istotny był niebywale szybko osiągnięty wysoki poziom alfabetyzacji społeczeństwa.

Wolne od kontroli społecznej polityczne elity Tajwanu monopolizowały wszystkie sektory, realizując skuteczny program rozwoju ekonomicznego. Dla KMT istniały dwie wartości naczelne, które za wszelką cenę należało zachować: hegemoniczna pozycja partii oraz ciągła modernizacja kraju (por. Weiner, 1966: 228-231). Gwarantując edukację i infrastrukturę, tajwańskie państwo-partia zapewniało stabilność kraju poprzez rozwiązywanie lub dławienie konfliktów i niepokojów społecznych. Przyciągało zagraniczne inwestycje i zapewniało elastyczność w przystosowaniu się państwa do wyzwań wewnętrznych i zewnętrznych ${ }^{4}$. Wypracowany system polityczny Tajwanu skutecznie realizował cele ekonomiczne, co pozwala określić go za Jurgenem Domesem jako zorientowany na rozwój system autorytarny, o którego specyfice stanowią dwie kluczowe cechy (Domes, 1981: 1011-1028; zob. także: Tai, 1970: 481-499; Gold, 1986):

Pierwszą jest nieingerowanie zmonopolizowanych przez KMT elit partyjnych w regulowanie wszystkich aspektów życia społecznego i politycznego, w przeciwieństwie do zorientowanych ideologicznie elit w systemach totalitarnych. Drugą cechą jest oparcie politycznego monopolu na zasadach rozwoju w kierunku rozwiniętego społeczeństwa masowego, a nie zachowaniu tradycyjnej struktury społecznej ${ }^{5}$.

\section{Okres przejściowy (1988-2003)}

W latach 70. XX wieku pozycja Tajwanu na arenie międzynarodowej zaczęła radykalnie słabnąćc. Główną przyczyną było zerwanie przez Stany Zjednoczone sto-

\footnotetext{
4 „Od 1953 do 1986 r. produkt narodowy brutto (GNP) przyrastał w tempie rocznym 8,8\%, zaś produkt brutto na jednego mieszkańca (GNP per capita) - 6,2\%. W roku 1989 dochód osiągnął poziom 7200 dolarów. O ile w 1951 r. dochód 20\% najbogatszych mieszkańców był 15 razy większy niż dochód 20\% najuboższych, o tyle do 1970 r. przepaść ta zwężała się do proporcji 4,58: 1, a następnie do 4,39: $1 \mathrm{w} 1983 \mathrm{r}$. Uczyniło to Tajwan jednym z najbardziej egalitarnych pod względem ekonomicznym społeczeństw świata. W konsekwencji ponad 50\% ludności Tajwanu zaliczało się do klasy średniej". Ka-Lok Chan, 1996: 123.

${ }^{5}$ Domes podaje tu przykłady systemów autorytarnych, zorientowanych zachowawczo: Hiszpania za Franco, Portugalia Salazara czy Filipiny za rządów Marcosa, cyt. za: Ka-Lok Chan, 1996: 124.

${ }^{6} \mathrm{Na}$ arenie międzynarodowej, w latach 1949-1971 Republika Chin na Tajwanie reprezentowała całe Chiny w ONZ i podobnie jako jedyne przedstawicielstwo Chin była uznawana przez wiele
} 
sunków dyplomatycznych z Tajwanem i nawiązanie ich z ChRL, która od 1972 roku reprezentowała już całe Chiny w $\mathrm{ONZ}^{7}$. W efekcie wpłynęło to na zmniejszenie rangi Tajwanu w stosunkach międzynarodowych powodując rosnącą izolację wyspy, która została wzmocniona podpisaniem Komunikatu Szanghajskiego przez prezydenta Stanów Zjednoczonych Richarda Nixona. Prezydent stwierdzał „Stany Zjednoczone akceptują przekonanie wszystkich Chińczyków mieszkających po obydwu stronach Cieśniny Tajwańskiej, że istnieją tylko jedne Chiny i że Tajwan jest częścią Chin” (R. Nixon, Komunikat Szanghajski, za: Wu-Ping, 2007: 105). W warunkach zaostrzonej izolacji Tajwan zmienił politykę „wyrażając milczącą zgodę na fakt uznawania przez świat dwóch bytów po obu stronach Cieśniny”, a wrogie nastawienie wobec kontynentu ustąpiło „idei pokojowego zespolenia obu obszarów w przyszłości” (Wu-Ping, 2007: 105).

W latach 80. XX wieku, w okresie prezydentury Chianga Ching-kuo, Kuomintang częściowo rozluźnił obowiązujące restrykcje i zaczął tolerować wyjazdy obywateli Tajwanu, odwiedzających krewnych na kontynencie. Nastąpiło również pokojowe wprowadzanie demokracji, a w polityce wewnętrznej wprowadzono kategorię „Nowych Tajwańczyków”. Rozpoczął się proces tajwanizacji celem zjednoczenia społeczności wyspy jako jednorodnego organizmu narodowego, co jednocześnie uznawano za ważny krok w staraniach o uczynienie $\mathrm{z}$ wyspy niepodległego państwa (Wu-Ping, 2007: 105). Pojawiły się inicjatywy zmierzające do demokracji, pluralizmu i równości społecznej, a także kapitalizmu i rozwoju technologicznego, które miały ogromny wpływ na system edukacji. Legalizacja w 1986 roku Demokratycznej Partii Postępu (DPP) zakończyła monopol KMT.

Zniesienie stanu wojennego i poważne zmiany w polityce wywołały daleko idące przeobrażenia edukacji. Znaczącym przykładem była bez wątpienia zmiana pozycji i roli nauczyciela - z modelu konfucjańskiego, w którym miał władzę absolutną, na osobę, która jest źródłem konkretnej i obiektywnej wiedzy. Zmianie uległa realizowana do tej pory edukacja moralna i obywatelska, która zaczynała być postrzegana jako dogmatyczna i anachroniczna w postępującym procesie modernizacji i transformacji społecznej (por. Sprenger, 1991: 155-176). W efekcie rząd wprowadził reformę programową, kładąc nacisk na zmianę treści i metody pracy nauczycieli edukacji moralnej i obywatelskiej. Celem było rozwiązanie problemów społecznych i dywersyfikacja społeczna. Antykomunistyczne i pronacjonalistycz-

\footnotetext{
krajów świata. W czasie „zimnej wojny” wyspa była pod parasolem USA i do 1971 roku uzyskiwała oficjalną pomoc i wsparcie.

${ }^{7}$ Władze ChRL podkreślały, iż problem Tajwanu jest wewnętrzną kwestią Chin, bowiem stanowi integralną część Państwa Środka.
} 
ne ideologie zostały pominięte na rzecz krytycznego rozumowania, czego szczególnie brakowało w autorytarnym programie nauczania (Lee, 2004: 582).

W 1993 roku ministerstwo edukacji przekazało szkołom podstawowym wytyczne programowe, które zawierały instrukcje w kwestiach moralności, posłuszeństwa, patriotyzmu i utrzymywania relacji z innymi ludźmi, społeczeństwem i środowiskiem. Dodatkowo program nauczania zawierał lekcje na temat świadomości zdrowotnej i krytycznego osądu. W przypadku gimnazjów zaimplementowano wytyczne dotyczące programu wiedzy o społeczeństwie tajwańskim oraz edukacji moralnej i obywatelskiej. Program nauczania dla szkół średnich miał za zadanie zaszczepić w uczniach reguły życia społecznego, odpowiedzialność, potrzebę współpracy i wzajemny szacunek, a także uznanie dla innych kultur etnicznych (Lee, 2004: 583-584).

Program nauczania edukacji obywatelskiej został zmieniony z modelu zorientowanego na język i kulturę chińską na model świadomości społecznej propagujący autochtoniczność, poprzez włączenie informacji o lokalnych tajwańskich zwyczajach, historii i geografii czy kwestiach wielokulturowych. Ponadto, w tym okresie wprowadzono do programu nauczania wiedzę na temat procesów demokratycznych i koncepcji prawnych. Innym ważnym aspektem było odteoretyzowanie treści programowych, dobrze widoczne w reinterpretacji tradycyjnej etyki konfucjańskiej bazującej na przykładach z codziennego życia. Częstą praktyką nauczycieli było uzupełnianie treści zawartych $\mathrm{w}$ podręcznikach gazetami lub materiałami związanymi z prawem i rozwijanie myślenia oraz dyskusji na temat aktualnych problemów, które budziły kontrowersje, a dotyczyły kwestii moralnych i społecznych. Organizowano także zajęcia ogólnoszkolne, mające na celu wypracowanie sposobów ograniczenia uprzedzeń i rozwijania większego szacunku wobec miejscowych mieszkańców i lokalnych wydarzeń. Jednakże, wskazywanymi przez Chi-Ming Lee trudnościami w realizowaniu nowego podejścia i większego zaangażowania nauczycieli był brak włączenia przedmiotu w zakres egzaminu wstępnego i, co się z tym wiąże, brak jego istotnego znaczenia w tajwańskim systemie edukacji (Lee, 2004: 583-584).

W końcu lat 80. XX. wieku rozpoczął się proces deregulacji w edukacji. Rząd zaczął dzielić się kontrolą z innymi agencjami, które wywierały coraz większy wpływ na kierunek reform edukacyjnych. Ukształtował się rynek podręczników, a rola prawa w zarządzaniu edukacją została wzmocniona. Nastąpiła zmiana alokacji struktury władzy wśród nauczycieli, dyrektorów i administracji oświatowej. Wzrosło również zainteresowanie opinii publicznej reformą edukacji. Zjawisko to nasiliło się po uchwaleniu w 1989 roku ustawy o organizacjach publicznych. W przyjmowanym kierunku reform istotne znaczenie odegrały: The Council for 
the Promotion of Teachers' Rights (Rada ds. Ochrony Praw Nauczycieli), The Humanistic Education (Fundacja Edukacji Humanistycznej) i Foundation Taiwan Teachers' Association (Tajwańskie Stowarzyszenie Nauczycieli). Stanowiły one coraz silniejszą grupę i stały się ważnymi graczami procesu reform, konsekwentnie wywierając presję na rząd. W efekcie powstał ruch na rzecz reformy edukacji obywatelskiej (Law, 2002: 61-81). Przykłady obejmują kampanię nauczycieli akademickich o autonomię uniwersytetów oraz projekty reform w zakresie kształcenia podstawowego i średniego postulowane przez różne grupy: nauczycieli, uczniów i ich rodziców, czy też organizacje religijne, które twierdziły, że edukacja na Tajwanie powinna być liberalna, demokratyczna, lokalna i apolityczna. Dla rządu oznaczało to konieczność balansowania pomiędzy skrajnymi wyborami (Song, 2009: 167-212). W tej sytuacji reforma edukacji stała się kontrowersyjnym obszarem polityki społecznej na Tajwanie, angażującym różne grupy społeczne. Ich skuteczność jest widoczna w przyjmowanej przez ministerstwo edukacji (TMOE) polityce i wyznaczanych propozycjach reform (Cheng-sheng, 2007: 11-14).

W oficjalnej ocenie system szkolny przenikało uczenie się na pamięć, eliminujące możliwości rozwoju kreatywności, wyobraźni, krytycznej analizy i zdolności do samodzielnego myślenia. Był to z pewnością akceptowany sposób uczenia się, zgodny z chińską tradycją, która służyła dobrze społeczeństwu przez co najmniej 2000 lat. Mistrzostwo wynikało z zapamiętywania i replikacji zgodnie z zasadą konfucjańską: „szanuj swoich przełożonych, zapamiętaj swoje lekcje i ćwicz nowe umiejętności wielokrotnie" (McKnight, 1994: 41). Niestety, w rzeczywistości szkolnej, w ramach istniejącego reżimu pamięciowego nauka geografii stawała się recytowaniem nazw geograficznych, nauka języka angielskiego ćwiczeniem w praktykowaniu zapamiętania odpowiedzi na pytania dotyczące gramatyki, nauka o literaturze testem umiejętności dosłownego cytowania fragmentów. Ponadto znacząca była prosta zależność, że jeśli nie jest się testowanym, nie jest się traktowanym poważnie (Sedlak, 1983: 415). Wśród nauczycieli powszechne było stanowisko, iż

wykonywanie testów i porównywanie osiągnięć zmusza ich do stawiania uczniom wyższych wymagań, ponieważ sami uczniowie stają się bardziej wymagający, podobnie rodzice i personel szkoły. Dla nich testy stanowią jedyny wskaźnik dydaktycznej skuteczności nauczycieli. Niestety, wspiera to rozrost instrukcji związanych z uczeniem się treści na pamięć. (Cheng, 1993: 10, za: Murphy, Liu, 1998: 12)

We wrześniu 1994 roku powołano Radę ds. Reformy Edukacji (Council on Education Reform). Podjęcie przez rząd decyzji o wprowadzeniu zmian było reakcją na rosnące niezadowolenie społeczeństwa z dotychczasowego systemu eduka- 
cji, który w odbiorze publicznym był oceniany jako 'zbyt sztywny'. Eksponowano brak możliwości wyboru przez uczniów własnej ścieżki edukacyjnej i gwarancji rozwoju indywidualnych różnic. Krytykowano także presję osiągnięć wywieraną na uczniów i eksponowano, iż uczenie się musi być postrzegane jako coś więcej niż tylko zdawanie egzaminów powiązane ściśle z pamięciową nauką obszernych, w większości nieprzydatnych treści. Główne założenia reformy zostały zaproponowane przez trzy grupy społeczne i dwie agencje rządowe. Grupy społeczne, o bardziej radykalnym podejściu, eksponowały potrzebę decentralizacji, uczestnictwa publicznego i bardziej pluralistycznej orientacji politycznej, czyli wskazywały na obszary odzwierciedlające szersze potrzeby zmian środowiska społeczno-politycznego Tajwanu. Inaczej program zmian akcentowały agencje rządowe, które w większym stopniu nastawione były na promowanie ulepszeń ogólnej jakości kształcenia (Murphy, Liu, 1998: 13-15).

Cele reformy obejmowały zwiększenie środków przeznaczonych na edukację, równość dostępu, poprawę jakości kształcenia nauczycieli, a także zmiany programów nauczania i podręczników. Zmniejszenie obciążeń uczniów było postrzegane jako priorytet reformy programowej. W nowych propozycjach programów i metod nauczania zostało to nagłośnione w haśle powrotu do normalności. Utworzona przez ministerstwo edukacji komisja miała ocenić i zweryfikować (uprościć) treści podręczników do liceum. Przykładowo: zredukować od 20 do 25 procent zawartość podręczników, wyeliminować niejednoznaczności, duplikaty i problemy z ciągłością. Jednak planowane zmiany treści nauczania nie spowodowały modyfikacji egzaminów wstępnych. Ministerstwo edukacji również próbowało zmniejszyć liczbę przedmiotów poprzez łączenie obszarów o podobnym charakterze. Dla przykładu: geografia, historia i wiedza o społeczeństwie zostały zintegrowane jako nowy przedmiot nauki społeczne, oraz fizyka, chemia, biologia i nauka o Ziemi miały się stać przedmiotem o nazwie nauka przyrodnicza. Zostało również zaproponowane, że programy nauczania elementarnego i gimnazjum powinny być bardziej powiązane z życiem ucznia i składać się z mniej izolowanych jednostek. Ponadto Rada ds. Reformy Edukacji, wprowadzając standardy edukacyjne, umożliwiła szkołom podejmowanie autonomicznych decyzji dotyczących programów nauczania. Zmiany programów nauczania oraz standardy edukacyjne miały umożliwić szkołom wpływanie na decyzje, co jest nauczane, i zachęcać nauczycieli do zaangażowania w rozwój programów. W efekcie istotne okazało się kilka zaleceń dotyczących nauczania, jak:

- redukcja maksymalnego czasu na kontakt nauczyciela z klasą do 20 godzin tygodniowo oraz wprowadzenie większej elastyczności w organizacji innych obowiązków zawodowych nauczyciela; 
- dwustopniowa redukcja liczebności klasy szkolnej. Do roku 1998 klasa szkolna miała liczyć maksymalnie 40 uczniów, zaś w 2006 liczba ta miała być zmniejszona do 30 uczniów;

- dostosowanie procesu dydaktycznego do indywidualnych potrzeb uczniów oraz warunków społeczno-kulturowych klasy;

- zmiana standardów efektywności dla każdego przedmiotu w celu oceny wyników uczniów i uzyskania informacji zwrotnej dla nauczycieli o potrzebie pomocy tym, którzy nie osiągają wystarczającego poziomu;

- zastąpienie 10-punktowej skali w systemie klasyfikacji skalą pięciopunktową. Podejście takie jest interpretowane jako środek ograniczający rywalizację między rówieśnikami;

- zachęcanie nauczycieli i uczniów do równego traktowania wszystkich przedmiotów, bez podziału na przedmioty 'o niskim lub wysokim statusie' (Murphy, Liu, 1998: 13-15).

\section{Czasy współczesne (od 2004 roku do dzisiaj)}

Istotnym wskaźnikiem demokratyzacji nowoczesnych społeczeństw XXI wieku jest zakres, w jakim prawa człowieka są wdrażane do praktyki codziennego życia. Niestety, na Tajwanie przez wiele lat zagadnienia praw człowieka były tematem tabu. Przełomowym był dopiero rok 2000, kiedy ministerstwo edukacji zorganizowało pierwszą konferencję prasową poświęconą prawom człowieka, zaś w 2001 roku ogłoszone zostały wytyczne dla edukacji o prawach człowieka. Działania te miały podkreślić tajwańską rezolucję o promowaniu praw człowieka w edukacji (Lee, 2004: 585-588). Zarówno rząd, jak i organizacje obywatelskie (np. Tajwańskie Stowarzyszenie Praw Człowieka) prowadziły serię działań promocyjnych na ten temat, skierowanych zarówno do uczniów, jak i nauczycieli. Edukacja na temat praw człowieka na Tajwanie powiązana została z zakazem kar cielesnych w szkołach, ograniczeniem dyscyplinujących metod $\mathrm{w}$ pracy nauczycieli z uczniami, tworzeniem bezpiecznego środowiska uczenia się wolnego od krytyki i przemocy, a także ze wzrostem szacunku wobec uczniów i obrony praw wolności (Lee, 2004: 585-588). Pod koniec 2003 roku założenia te stanowiły już wytyczne ministerstwa edukacji, które miały być realizowane w wyniku zintegrowanych działań nauczycieli, uczniów, administracji, rodziców oraz społeczności lokalnej. W procesie tworzenia „szkoły jakości” kluczowe były dwa założenia: pierwsze wiązało się ze wzmocnieniem roli rodziców w edukacji, drugie ze stanowiskiem, iż jakość edukacji to właśnie polityka szkolna i profesjonalizm nauczycieli. 
W nowym tysiącleciu reformy edukacji promowały bardziej postępowe postawy, decentralizację, autonomię lokalną oraz prawa uczniów, rodziców i nauczycieli (Chen, 2008: 293-294). Do szkół wprowadzane zostały programy rodzicielskie, by sami rodzice coraz częściej angażowali się w działania szkolne. Istotnym obliczem przemian społeczno-kulturowych była redefinicja roli płci i rodzicielstwa, co wyraźnie przejawiało się w celach edukacji moralnej i obywatelskiej (Ho, Lam, Yeh, 2013: 365).

Po zakończeniu okresu przejściowego w 2003 roku i z początkiem rządowego trendu deregulacyjnego podręczniki kształtowania charakteru nie podlegały już kontroli Narodowego Instytutu Kompilacji i Tłumaczeń ani nie były już przez ten instytut wydawane. Co ważniejsze, zgodnie z utworzonymi w 2004 roku przez TMOE wytycznymi kształcenie w zakresie edukacji moralnej zostało włączane w lekcje wiedzy o społeczeństwie na poziomie szkoły podstawowej i średniej i było wzorowane na podstawie programowej opracowanej w Stanach Zjednoczonych (Doong, 2008). Treści eksponowały szacunek wobec odmiennej płci, etnicznego oraz społeczno-ekonomicznego statusu jednostek i grup, a także troskę o przyrodę i środowisko. Rezygnacja z oddzielnego przedmiotu szkolnego w zakresie edukacji moralnej wywołała wiele wątpliwości zgłaszanych przez nauczycieli i urzędników szkolnych. Ministerstwo (TMOE) wydało w 2004 roku Program Doskonalenia Edukacji Moralnej i Obywatelskiej (Moral and Character Education Improvement Program, MCEIP), którego celem uczyniono: rozwijanie umiejętności moralnej argumentacji uczniów, zachęcanie do tworzenia kreatywnych, demokratycznych strategii, kształtowanie i integrowanie wartości w formalnych, nieformalnych i ukrytych programach nauczania, wspieranie szkoły w budowaniu kultury zorientowanej na potrzeby uczniów; umożliwienie uczniom, pracownikom szkół, rodzicom i liderom społeczności szkolnej udziału w kulturze szkolnej w oparciu o kształtowanie charakteru; wsparcie organizacji pozarządowych, fundacji związanych z kulturą oraz środków masowego przekazu. Osiągnięcie zakładanych celów miało przyczynić się do lepszego zrozumienia przez uczniów powiązań pomiędzy edukacją moralną a doświadczaniem codziennego życia i przygotowania do bycia pełnoprawnymi obywatelami świata (Lee, 2009: 165-184). Wsparciem w realizacji nowego programu MCEIP miały być opracowane przez ministerstwo TMOE wskaźniki efektywności (Lee, 2004: 585-588) oraz skierowany do szkół ogólnokrajowy konkurs sprawdzający kreatywność nauczycieli w realizacji celów i tworzeniu innowacyjnych działań edukacyjnych (Lee, 2009: 166).

Wprowadzanie nowych wartości w system edukacji (czy szerzej społeczny) nie jest sprawą prostą. Z jednej strony nowe wartości wzmacniać miały siłę indywidualności - niezbędną w rozwoju kreatywności, innowacyjności, a zatem konkuren- 
cyjności społeczeństwa, z drugiej jednak strony nie mogą one zaistnieć kosztem wartości akceptowanych i mocno utrwalonych w społeczeństwie. W 2009 roku przeprowadzone zostały badania w obszarze kultury tajwańskich szkół, podczas których uczniowie, rodzice i personel szkolny mieli wytypować podstawowe wartości do realizacji przez szkoły (Cheng-sheng, 2007). Nie jest zaskoczeniem, że wiele z nich odzwierciedlało idee konfucjańskie. W oparciu o wytypowane kluczowe dla społeczności szkolnej wartości powstał zbiór formalnych i nieformalnych aktywności, stworzony przez praktyków i naukowców. Obejmowały one między innymi: dyskusje na kontrowersyjne tematy, poruszanie podczas lekcji „dylematów moralnych" przez uczniów czy konstruowanie międzyszkolnych zajęć dydaktycznych, które angażują uczniów w procesy decyzyjne (Lee, 2009).

Można przyjąć, iż współcześnie kluczowym wyzwaniem staje się zrównoważenie wartości konfucjańskich z potrzebą etyki moralnej i obywatelskiej. Integracja globalnych wpływów z lokalnymi, bez burzenia tożsamości, była i nadal jest najważniejszą kwestią w planowaniu zmian edukacji (Cheng-sheng, 2007). Niektórzy badacze krytykują tajwańskie społeczeństwo za przestrzeganie tradycyjnych wartości, identyfikując takie zachowanie jako przeszkodę w kształtowaniu charakteru młodzieży we współczesnym, pluralistycznym społeczeństwie. W publikacjach powszechny jest pogląd, iż nowoczesne społeczeństwa zapewniają platformy, na których ludzie, "testują" i weryfikują swoje opinie, bowiem ujawniając, je poddają automatycznie publicznej krytyce. Jednakże wszechobecna na Tajwanie kultura utrwala status quo, w efekcie blokuje lub nawet uniemożliwia krytyczne myślenie i wiąże jednostkę z bezmyślnym zachowaniem tradycyjnych cnót. Stąd coraz częściej można spotkać się ze stanowiskiem uzasadniającym, iż jedyną drogą dla Tajwanu jest przejście przez moralny relatywizm, by w dalszej kolejności móc zbudować odpowiednio nowoczesny i uniwersalny system wzniesiony na wartościach: demokracji, sprawiedliwości i troski o obywatela (Lee, 2004: 590). Przywołane dylematy świadczą o istnieniu napięcia między nowoczesnymi i tradycyjnymi wartościami, a pokonanie ich będzie rzutować na przyszły kształt edukacji na Tajwanie.

\section{Podsumowanie}

Chociaż proces demokratyzacji Tajwanu, dokonujący się stopniowo od lat 80 . XX wieku, nie budzi wątpliwości, to jednak utrwalona przez lata silna autonomia państwa-partii, jak i ograniczone współczesne możliwości wynikające ze sprzecznych żądań wynikających zarówno z polityki wewnętrznej, jak i międzynarodowej, składają się na trudną sytuację, niemającą podobnej w Azji Wschodniej. W roz- 
bieżnych poglądach rządów po obu stronach Cieśniny Tajwańskiej wciąż otwartą kwestią pozostaje, na ile skutecznie (lub czy jest to w zasadzie możliwe i sensowne) Tajwan może przejść od zorientowanego na rozwój systemu autorytarnego do zorientowanego na rozwój systemu demokratycznego, zapewniającego utrzymanie silnego państwa zaspokajającego oczekiwania społeczne i rozwiązującego kwestie sporne?

Jednak społeczeństwo tajwańskie się zmienia. Mało tego, obserwowane zmiany nastąpiły w tempie o wiele szybszym niż w większości uprzemysłowionych narodów. Podczas gdy proces industrializacji i urbanizacji w Stanach Zjednoczonych trwał 50 lat, na Tajwanie mniej niż 20 lat. Stawki wzrostu PKB były w porządku $8 \%$ rocznie od 1970 roku. Na tym tle proces transformacji Tajwanu ukazuje przejście z gospodarki w dużej mierze agrarnej do tworzącego się społeczeństwa poprzemysłowego. Jednak nie tylko istotny jest sam proces przejścia, ale i jego tempo, bowiem odbyło się to trzy razy szybciej niż wielkie zmiany w okresie rewolucji przemysłowej w Wielkiej Brytanii (Wu-Ping, 2007). Podobnie do tempa rozwoju gospodarczego rozwijał się system edukacji Tajwanu. Edukacja była i jest areną rozwijania, manifestowania, konsolidacji i przekazywania demokratycznych ideałów, poszanowania etnicznych i kulturowych różnic oraz wspierania 'nowej tożsamości narodowej' - obywatela Tajwanu. Równie szybki był proces przejścia z nauczania (głównie w oparciu o metody podające) do uczenia się i pomocy skierowanej do uczniów w nabywania umiejętności samodzielnego kierowania uczeniem się - jako podstawy edukacji całożyciowej (Clark, 2010).

Pokojowe przekazywanie władzy w 2000 roku z KMT do DPP stało się wymiernym dowodem dość ugruntowanej demokracji. Zaistniałe zjawisko badacze wyjaśniają istnieniem dwóch grup wzajemnie powiązanych czynników. W pierwszej zawierają się warunki społeczno-ekonomiczne sprzyjające rozwojowi demokracji, jak: pomyślny wzrost gospodarczy, popyt przedsiębiorców i profesjonalistów na większą autonomię, rozwój klasy średniej, wzrost poziomu wykształcenia społeczeństwa, interakcje ze światem zewnętrznym, w szczególności z państwami zachodnimi oraz w wyniku postępującego handlu konieczność ustosunkowania się do wartości demokratycznych i ich transfer. Druga grupa czynników ma charakter społeczno-polityczny i dotyczy redystrybucji władzy między państwem a społeczeństwem, co spowodowało, że demokratyzacja na Tajwanie stanowi pokojowe przejście bez rozlewu krwi czy rewolucji (por. Wu-Ping, 2007; Ka-Lok Chan, 1996). W procesie tym istotne były dwa etapy: transformacja $\mathrm{z}$ ustroju autorytarnego do demokracji w ramach dominacji KMT (pierwsze wybory prezydenckie w 1996) oraz etap drugi: przekazanie władzy z KMT do DPP w wyborach prezydenckich w 2000 roku. Organizacja i funkcjonowanie różnego szczebla insty- 
tucji na Tajwanie stwarza obywatelom możliwości czynnego uczestnictwa w życiu politycznym, w tym organizowanie opozycji.

Proces demokratyzacji życia społecznego na Tajwanie został skonfrontowany z konfucjanizmem wspieranym przez system edukacji (Pan, 2007: 277). Wielu badaczy postrzegało konfucjanizm jako politycznie krępujący, a nawet uważało, że ma opresyjny wpływ na rozwój kapitalizmu; przykładowo, Max Weber utożsamiał go z siłą, która przyczyniła się do opóźnienia rozwoju gospodarczego Chińczyków. W jego ocenie uznanie niezmienności porządku społecznego, przywiązanie do swoich przodków, a także krytyka pogoni za bogactwem dyskredytowały rozwój gospodarczy społeczeństw i były dowodem na historyczną przewagę Zachodu (Weber, 2010; Weber, 1968). Jednak założenia Webera nie znalazły potwierdzenia na Tajwanie. Roderick MacFarquhar na początku lat 80. XX wieku opublikował artykuł w „The Economist”, w którym ukazywał związek pomiędzy konfucjanizmem a aktywnością gospodarczą (kapitalizmem) i podkreślał jego pozytywną rolę w rozwoju gospodarczym (szerzej: Suleski, 2005). Równie znaczącą siłą przemian na Tajwanie okazała się edukacja, którą w 1996 roku premier Lien Chan uznał za kluczowy czynnik odpowiedzialny za osiągnięcia gospodarki i polityki Tajwanu (Cheng-sheng, 2007).

Niestety, w procesie zmiany, jak zauważa Lee, system oparty na starych wartościach moralnych 'zbankrutował', podczas gdy nowy, bardziej otwarty, jeszcze nie został ustanowiony. Dlatego niektórzy są skłonni do przyjęcia moralnego relatywizmu, który może skutkować brakiem spójności społecznej i budowania odpowiednio nowoczesnego systemu wartości odnoszących się do demokracji, sprawiedliwości i troski o obywateli (Lee, 2012, za: Ho, Lam, Yeh, 2013: 366). Wymaga to bez wątpienia podejścia systemowego i współpracy oraz pozytywnego oddziaływania w rodzinie, w szkole i społeczeństwie. Taki kierunek prowadzi do konieczności odpowiedzi na pytania; jak zrównoważyć kulturę Wschodu i Zachodu i uniknąć kryzysu tożsamości kulturowej? W jaki sposób edukacja może pomóc w zmniejszeniu napięcia wywołanego przez przeciwstawne ideologie polityczne? Są to pytania, których rozwiązanie w sposób pokojowy musi prowadzić przez edukację, i na które Tajwan wciąż poszukuje nowych odpowiedzi.

\section{Literatura}

Chen P. (2008). Strategic leadership and school reform in Taiwan. "School Effectiveness and School Improvement" vol. 19, nr 3, s. 293-318.

Cheng T. (1993). Learning to Read in Chinese First Grade Classrooms (ERIC Document Reproduction Service No. ED 362 581). 
Cheng-sheng T. (2007). Taiwan's Educational Reform and the Future of Taiwan, Minister of Education, Taiwan and Member of the Academia Sinica, Taipei Presented at London School of Economics and Political Science January 10, 2007. http://www.lse.ac.uk/researchAndExpertise/units/TaiwanProgramme/Events/PublicLectures/TaiwanEducationalReform_English.pdf dostęp: 20.12.2017.

Clark N. (2010). Education in Taiwan. "World Education News \& Reviews" https://wenr.wes. org/2010/05/wenr-may-2010-feature, dostęp: 20.12.2017.

Copper J.F. (2013). Taiwan. Nation-State or Province? Wyd. VI. Boulder, CO.

Domes J. (1981). Political differentiation in Taiwan: group formation within the Ruling Party and till Opposition Circles 1979-80. „Asian Survey”, nr 10, s. 1011-1028.

Doong S. (2008). Taiwan's new citizenship curriculum: Changes and challenges. [w:] D.L. Grossman, W.O. Lee, K.J. Kennedy (eds). Citizenship curriculum in Asia and the Pacific. Hong Kong, s. 43-60.

Education in Taiwan, [w:] World Education News \& Reviews. https://wenr.wes.org/2010/05/wenr-may-2010-feature, dostęp: 20.12. 2017.

Gold T.B. (1986). State and Society in the Taiwan Miracle. Sharpe: N.Y.

Ho H.-Z., Lam Y.W. Yeh K.-H. (2013). Character education in Taiwan: A reflection of historical shifts in sociocultural contexts. "Childhood Education" vol. 89, s. 362-367.

Hung T.-Y. (2007). American new character education movement and its implication for grade 1-9 curriculum in Taiwan. "School Administration Bi-monthly" nr 48, s. 300-314.

Ka-Lok Chan K. (1996). Państwo autorytarne a tajwański cud gospodarczy. „Studia Polityczne” nr 5, s. $117-126$.

Law W.-W. (2002). Education reform in Taiwan: A search for a 'national' identity through democratisation and Taiwanisation. "Compare: A Journal of Comparative and International Education" vol. 32, s. 61-81.

Lee C.-M. (2004). Changes and challenges for moral education in Taiwan. "Journal of Moral Education" nr 33(4), s. 575-595.

Lee C.-M. (2009). The planning, implementation, and evaluation of a character-based school culture project in Taiwan. "Journal of Moral Education" nr 38(2), s. 165-184.

Lee C.-M. (2012). Moral and character education in Taiwan: History and lessons to be drawn. Referat opracowany na: The Jubilee Centre for Character and Values, Character and Public Policy: Educating for an Ethical Life, University of Birmingham, United Kingdom.

Liu C. (1958). A Report on Education to the Provincial Assembly. Department of Education, Taiwan Provincial Government: Taiwan.

Liu C. (1977). Education is Dedication. Taipei, Taiwan.

Liu M. (2002). Civic education at the crossroads. [W:] J.J. Cogan, P. Morris, M. Print (eds). Civic Education in the Asia-Pacific Region. New York, NY, s. 93-117.

McKnight A. (1994). Chinese learners of English: A different view of literacy? "Open Letter" nr 4 (2), s. $39-52$.

Meyer J.F. (1988). Moral education in Taiwan. "Comparative Education Review" nr 32(1), s. 20-38.

Ministry of Education Republic of China, Education in Taiwan, Department of Statistics, Taipei 2013/2014, s. 8-10. https://stats.moe.gov.tw/files/ebook/Education_in_Taiwan/2013-2014_ Education_in_Taiwan.pdf, dostęp: 20.12.2017.

Murphy C., Liu M. (1998). Choices must be made. The case of education in Taiwan. "Education" nr 3(13), s. 9-16.

Pan H.-L. (2007). School effectiveness and improvement in Taiwan. [W:] T. Townsend (ed.). International Handbook of School Effectiveness and Improvement. Dordrecht. 
Sedlak P. (1983). An evaluation of EFL methodology in the R.O.C. [W:] C. Feng-Pu (ed.) EFL Readings for Chinese Teachers. Taipei, s. 413-417.

Smith D. (1992). The Chinese family in transition: implications for education and society in modern Taiwan', Paper presented at the Comparative Education Association/World Bank Seminar, Annapolis, Maryland (ERIC Document Reproduction Service No. ED 352 295).

Song X. (2009). Between Civic and Ethnic The Transformation of Taiwanese Nationalist Ideologies (1895-2000). Brussels.

Sprenger A. (1991). Higher moral education in Taiwan. [W:] T. Van Doan, V. Shen, G.F. McLean (eds). Chinese Foundations for Moral Education and Character Development. Washington, DC, s. $155-176$.

Suleski R.S. (2005). The Fairbank Center for East Asian Research at Harvard University: a Fifty Year History, 1955-2005. Cambridge.

Tai H.C. (1970). The Kuomintang and modernization in Taiwan. [W:] S.P. Huntington, C.H. Moore (eds). Authoritarian Politics in Modern Society. New York.

Weber M. (1968). The Religion of China: Confucianism and Taoism. New York.

Weber M. (2010). Etyka protestancka a duch kapitalizmu. Warszawa.

Weiner M. (1966), Political participation and political development. [W:] M. Weiner (ed.), Modernization: The Dynamics of Growth, Washington, D.C., s. 228-231.

Winckler E.A. (1984). Institutionalization and participation on Taiwan: From hard to soft authoritarian? "China Quarterly" s. 481-499.

Wu-Ping K. (2007), Wpływ stosunków chińsko-tajwańskich na rozwój gospodarczy Tajwanu. „Studia i Materiały" nr 2, s. 104-109.

Yao Z. (2000). An Introduction to Confucianism. Cambridge.

Young Y.R. (1995). Taiwan. [W:] P. Morris, A. Sweeting (eds). Education and Development in East Asia. New York, s. 105-124. 